\title{
Editorial
}

\section{Beti bachao, beti padhao programme: a right initiative to save the girl child}

\author{
Ramesh Verma, Rohit Dhaka*, Ginni Agrawal
}

\author{
Department of Community Medicine, Pt B D Sharma PGIMS Rohtak, Haryana, India

\section{*Correspondence:} \\ Dr. Rohit Dhaka, \\ E-mail: dr.rohitdhaka@gmail.com
}

Copyright: (c) the author(s), publisher and licensee Medip Academy. This is an open-access article distributed under the terms of the Creative Commons Attribution Non-Commercial License, which permits unrestricted non-commercial use, distribution, and reproduction in any medium, provided the original work is properly cited.

The Census data in India showed a significant declining trend in child sex ratio (0-6 years) from 945 girls /1000 boys in 1991 to 927 in 2001 and further to 918 in 2011. The steep downfall in the child sex ratio is a prime indicator of women disempowerment, lack of value attached to her and disrespect. Women make up for almost half of the total population of India but they still lag behind men in a lot of areas. It is harrowing that a lot of females are not even allowed to be born. Many of those who are fortunate enough to see this world are denied of some of their most basic rights: quality education and healthcare. Many are married off in their teenage. ${ }^{1}$

Over the last many years, a significant fraction of number of women has been at the receiving end of discrimination and exploitation. The down child sex ratio is because of both pre birth discrimination manifested through gender biased sex selection, and post birth discrimination against girls. Social discriminating against girls is one part, easy availability, affordability and subsequent misuse of ultrasonography on the other hand, have been critical in increasing Sex selective elimination of girls leading to low child sex ratio. This decline is widespread across the country and has expanded to rural as well as tribal areas. The most important factor responsible for decreasing child sex ratio is the low status of Indian women coupled with traditional gender bias. The needs with regards to health, nutrition and education of a girl child have been neglected. As mentioned in the vedic age (1500-1000 BC), they were worshipped as goddesses. However, with the passage of time, their status underwent insignificant and sharp decline and they were looked down upon as 'slaves of slaves'. ${ }^{1}$
Most of the factors that compel people to favor a male offspring are social and religious in origin. With the average family size decreasing rapidly and preference for male child remaining the same, the female population is showing a downward trend. The birth of female child is perceived as a curse with economic and social liability. The proliferation and abuse of advanced technologies coupled with social factors such as dowry, concerns with family name and looking up to the son as a breadwinner, contributing to the low status of women, have made the evil practice of female feticide common in the middle and higher socioeconomic households, more so in the north Indian states. Advances in technology and diagnostic facilities have opened up avenue for the girl haters leading to serious disturbances in the sex ratio as a result of female feticide. Desire for male child manifests so blatantly that parents are terminating girl child before she born. Female feticide resulting in a decline of the child sex ratio has led to enforcement of Preconception and Prenatal diagnostic Techniques (PC \& PNDT) act.

To keep in mind about this alarming situation, Prime Minister of India launched the scheme on 22 January 2015 at Panipat in Haryana, Beti Bachao, Beti Padhao (Save daughters, Educate daughters) programme. The initiative aims to improve the present low child sex ratio and increase the value of girl child by focusing on three pronged strategies for empowerment of girl child: a) Raising awareness on sex selective abortions for attitudinal change, b) better implementation of PC \& PNDT Act, c) The coordinated \& convergent efforts are needed to ensure survival, protection and education to improve quality of life of girl child. 
The overall goal of the scheme is to celebrate the girl child \& enable her education and the objectives of the scheme are as follows. ${ }^{2}$

\section{To prevent gender based sex selective abortion}

Child sex ratio puts a light on the pre-birth discrimination on the basis of gender that manifests in the form of unacceptable practice of female feticide. Convergent efforts by government agencies and non-government organizations (NGOs) are crucial to ensure survival, safety and empowerment of the fairer sex. Under the scheme, district authorities are required to effectively monitor and ensure that the use of sex-determination tools by families and doctors lead to stringent action by law. Several healthcare centers indulging in such practices have been sealed owing to this programme. Parents, families, doctors and the community at large are being oriented to not resort to sex-determination during pregnancy.

\section{To ensure survival and protection of the girl child}

This programme is being implemented with full commitment of political leaders and government officials across the country. The central government officials are working in close coordination with state officials to ensure survival, well-being, security and education of the girl children. The government has been actively working to integrate the BBBP with other schemes that have been implemented for the well-being of girls in India. Several sub-schemes have also been rolled out as a part of the umbrella BBBP scheme like Sukanya Samriddhi scheme is a small savings scheme wherein the parents of a girl or a legal guardian can open a dedicated savings account for her in any post office or in some of the authorized commercial banks.

\section{To ensure education of the girl child}

The education of girl child is a very significant aspect of the BBBP scheme. Right to Education Act, 2010 entitles every child the right to free education till the completion of elementary education in a neighborhood school. Unfortunately, the Act does not see its proper implementation in letter and spirit. If the girls are educated properly, they will grow up to be selfempowered individuals, better equipped to take their socio-economic decisions in their own and society's best interests. Under the BBBP scheme, district-level education officials have to ensure that the benefit of free elementary education reaches all the girls. There should be active involvement of schools and other grass rootlevel organizations to success this task. The school management committees should achieve $100 \%$ transition of girl students at various educational levels are awarded under the BBBP scheme.

\section{Community responsibility}

Community participation is a proven approach for the success of programme. The community should celebrate the birth of girl child in the family and community. Take pride in daughters and oppose the mentality of 'Bojh' and 'Paraya Dhan'. Find ways to promote equality between boys and girls. Secure admission to \& retention of girl child in schools. Engage men and boys to challenge gender stereotypes and roles. Educate and sensitize our sons to respect women and girls as equal members of society. Report any incident of sex determination test. Strive to make neighborhood safe \& violence-free for women and girls. Oppose dowry and child marriage within the family and community. Advocate simple weddings. Support women's right to own and inherit property. Encourage women to go out, pursue higher studies and work, do business, access public spaces freely etc. Mind their language and be sensitive towards women and girls.

\section{Components of the programme $e^{3}$}

Mass communication campaign: The campaign aims at ensuring girls are born, nurtured and educated without discrimination to become empowered citizens of this country. The Campaign interlinks National, State and District level interventions with community level action bringing together different stakeholders for accelerated impact.

Multi-sectoral interventions: The coordinated \& convergent efforts are undertaken in close coordination with Ministry of Health and Family Welfare and Ministry of Human Resource Development to ensure survival, protection and education of the girl child. The District Collectors/Deputy Commissioners lead and coordinate actions of all departments for implementation of BBBP at the district level. Multi-sectoral interventions includes: i) ministry of women child development: promote early registration of pregnancies in first trimester in Anganwadi centres; undertake training of stakeholders; community mobilization \& sensitization; Involvement of gender champions; reward and recognition of institutions and frontline workers. ii) Ministry of Health \& Family Welfare: Monitor implementation of pre-conception and pre-natal diagnostic techniques (PC \& PNDT) Act, 1994; Increased institutional deliveries; Registration of births; Strengthening PC \& PNDT Cells; Setting up Monitoring Committees iii) Ministry of Human Resource Development: Universal enrolment of girls; Decreased drop-out rate; Girl Child friendly standards in schools; Strict implementation of Right to Education; Construction of Functional Toilets for girls.

Haryana State had the worst sex ratio 834:1000 among all states in the country as per census 2011 and in the year 2017 , the state has achieved child sex ratio of 914 girls as against 1000 boys for the first time since 2001 as per registration of births in the state. In Haryana, 17 districts 
of the state have achieved sex ratio at birth of 900 or more and no district has recorded sex ratio at birth below 880. District Panipat tops the list in sex ratio at birth as 945 followed by district Yamunanagar with 943. According to 2011 census, districts Mohindergarh, Rewari, Sonipat and Jhajjar shown the child sex ratio below the 800, but after the launched of BBBP, now they have shown remarkable improvement. District Mohindergarh has shown improvement of 136 points, Rewari has improved by 91 points while district Sonipat has improved 88 point and Jhajjar district improved 96 points. ${ }^{4}$ This improvement was made possible due to effective implementation of the law against illegal sex determination and female foeticide. State had launched a massive drive against sex determination, sex selective abortion and female foeticide after the launch of BBBP and also extensive interventions was undertaken to curb the illegal practices by strict enforcement of PC \& PNDT Act and Medical Termination of Pregnancy Act in the state. During this campaign inter-district as well as interstate raids were planned and implemented with the help of the concerned authorities of the neighbouring states to catch the culprits engaged in cross border sex determination followed by female foeticide.

In conclusion, the Government of India took a good initiative through the Beti Bachao Beti Padhao scheme to address the issues revolving around girl children, right from the time they aren't even born up to adults.

\section{REFERENCES}

1. Verma R. Gender inequality and Women empowerment. 1st Ed. 2011. LAP LAMBERT Academic Publishing. Germany; 2011.

2. National Mission for Empowerment of Women. Ministry of Women and Child Development, Government of India. Available at: http://www.nmew.gov.in/index.php. Accessed on 30 January 2018.

3. Beti Bachao, Beti Padhao Government of India. Available at: http://wcd.nic.in/BBBPScheme/ main. htm. Accessed on 30 January 2018.

4. Financial Express Read to Lead (January 15, 2018). Sex ratio in Haryana is best in decades; 'Beti Bachao-Beti Padhao' scheme behind success. Available at: http://www.financialexpress.com/ india-news/sex-ratio-in-haryana-is-best-in-decadesbeti-bachao-beti-padhao-scheme-behindsuccess/1014605. Accessed on 30 January 2018.

Cite this article as: Verma R, Dhaka R, Agrawal G. Beti bachao, beti padhao programme: a right initiative to save the girl child. Int J Community Med Public Health 2018;5:2153-5. 